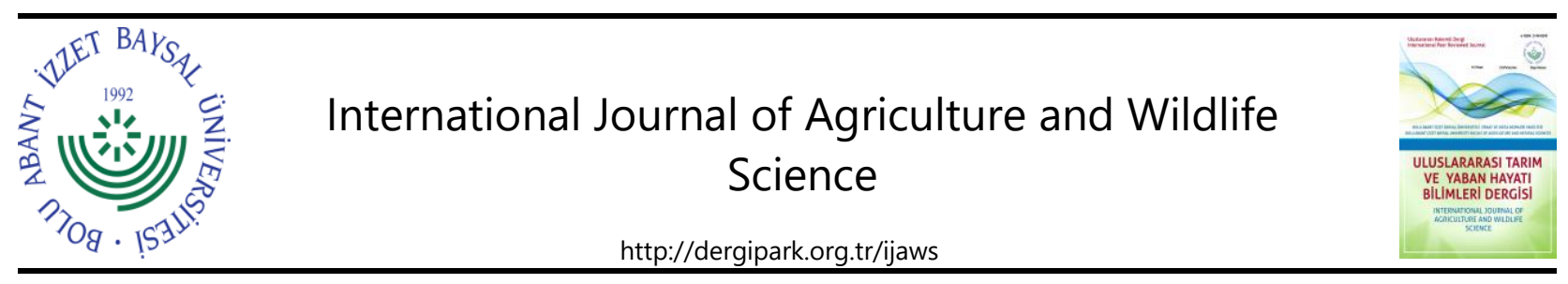

Research Article

\title{
Antioxidant Enzyme Activities of Some Wild and Cultivated Edible Mushrooms in Turkey
}

\author{
Nezahat Turfan', Sezgin Ayan², Aysun Pekşen ${ }^{3 *}$, Şeyma Selin Akın ${ }^{4}$ \\ ${ }^{1}$ Kastamonu University, Sciences and Arts Faculty, Department of Biology, Kastamonu, Turkey \\ 2Kastamonu University, Faculty of Forestry, Silviculture Department, Kastamonu, Turkey \\ ${ }^{3}$ Ondokuz Mayıs University, Faculty of Agriculture, Department of Horticulture, Samsun, Turkey \\ ${ }^{4}$ Kastamonu University, Institute of Science, PhD Program of Sustainable Forestry, Kastamonu, Turkey
}

\section{Keywords:}

Antioxidant,

enzyme,

mushroom carotene,

lycopene,
*Corresponding author aysunp@omu.edu.tr
Abstract. In this study; wild and cultivated edible mushrooms [Boletus edulis Bull.: Fr, Craterellus cornucopioides (L.) Pers., Lactarius deliciosus (L. ex Fr.) S.F.Gray, Laetiporus sulphureus (Bull.: Fr.) Murr., Marasmius oreades (Bolt. ex Fr.) Fr., Morchella conica Pers., Ramaria botrytis (Pers.: Fr.) Ricken, Tricholoma terreum (Schaeff.: Fr.) P. Kumm., Hericium erinaceus (Bull.: Fr.) Pers., Lentinula edodes (Berk.) Pegler, Ganoderma lucidum (Curt.: Fr.) P. Karst., and Pleurotus ostreatus (Jacq. ex Fr.) P. Kumm. (1-4)] were obtained from different locations in Turkey. Phenylalanine ammonia lyase (PAL) enzyme activity, ascorbate peroxidase (APX), peroxidase (POD), and superoxide dismutase (SOD) activity changes and nitrate, $\beta$-carotene and lycopene levels were investigated in 15 samples to determine antioxidant enzyme capacity. As a result of the study, the highest amount of $\beta$-carotene and lycopene were determined in $H$. erinaceus. $P$. ostreatus -2 had the lowest amount of $\beta$-carotene, whereas Pleurotus ostreatus- 1 had the lowest amount of lycopene. Species rich in nitrate content were $C$. cornucopioides and $P$. ostreatus-4. P. ostreatus-3 was the poorest species in terms of nitrate compared to other mushroom samples. PAL activity of mushrooms varied between 5.863 and $8.893 \mathrm{EU} \mathrm{mg}^{-1}$ protein. For APX values, $P$. ostreatus -4 had the highest value, while $H$. erinaceus species had the lowest value. Among mushroom species, the highest and the lowest POD values were determined in $H$. erinaceus and $B$. edulis, respectively. C. cornucopioides had the highest and $P$. ostreatus- 3 had the lowest SOD values.

\section{Türkiye'deki Bazı Doğa ve Kültürü Yapılan Yenebilir Mantarların Antioksidan Enzim Aktiviteleri}

\section{Anahtar kelimeler:} Antioksidan, karoten, enzim, likopen, mantar

\section{Özet. Bu çalışmada; Türkiye'nin farklı yörelerinden temin edilen 15 doğa ve kültür mantar türüne} [Boletus edulis Bull.: Fr, (Ayı mantarı), Craterellus cornucopioides (L.) Pers. (Borazan mantarı), Lactarius deliciosus (L. ex Fr.) S.F.Gray (Kanlıca mantarı), Laetiporus sulphureus (Bull.: Fr.) Murr. (Kükürt mantarı), Marasmius oreades (Bolt. ex Fr.) Fr. (Cincile mantarı), Morchella conica Pers. (Kuzugöbeği mantarı), Ramaria botrytis (Pers.: Fr.) Ricken (Pürpürüm mantarı), Tricholoma terreum (Schaeff.: Fr.) P. Kumm. (Karakız mantarı), Hericium erinaceus (Bull.: Fr.) Pers. (Aslan yelesi mantarı), Lentinula edodes (Berk.) Pegler (Meşe mantarı), Ganoderma lucidum (Curt.: Fr.) P. Karst. (Reishi mantarı) ve Pleurotus ostreatus (Jacq. ex Fr.) P. Kumm. (1-4) (Kayın mantarı)] ait örnekte antioksidan enzim kapasitesini belirlemek için fenilalanin amonyum liyaz (PAL) enzim aktivitesi, askorbat peroksidaz (APX), peroksidaz (POD) ve süperoksid dismutaz (SOD) aktivite değişimleri ve nitrat, $\beta$-karoten ile likopen düzeyleri araştııı Imıştır. Sonuç olarak, farklı yörelerden temin edilen mantar örnekleri içerisinde en yüksek $\beta$-karoten ve likopen miktarı $H$. erinaceus türünde belirlenmiştir. $\beta$-karoten miktarının en düşük olduğu tür $P$. ostreatus- 2 iken en düşük likopen miktarı $P$. ostreatus-1 türünde saptanmıştır. Nitrat içeriği bakımından zengin olan türler; $C$. cornucopioides ve $P$. ostreatus- 4 olarak tespit edilmiştir. $P$. ostreatus-3, diğer mantar örneklerine kıyasla nitrat bakımından en fakir tür olarak belirlenmiştir. Mantarların PAL aktivitesi 5.863 ve $8.893 \mathrm{EU}$ $\mathrm{mg}^{-1}$ protein arasında değişmiştir. En yüksek APX değerinin $P$. ostreatus-4 türüne, en düşük değerin ise $H$. erinaceus türüne ait olduğu bulunmuştur. Mantar türleri arasında en yüksek ve en düşük POD değerleri sırasıyla $H$. erinaceus ve $B$. edulis türlerinde saptanmıştır. SOD değeri en yüksek tür $C$. cornucopioides, en düşük tür ise $P$. ostreatus-3 olarak belirlenmiştir. 


\section{INTRODUCTION}

Mushrooms are important food sources in terms of nutritional and medicinal values. They have been consumed as food since ancient times thanks to their nutritional properties and aromas (Barros et al., 2008a; Wasser, 2014). Edible mushrooms contain $88-94 \%$ water, $15-42 \%$ protein, $2-6 \%$ crude fat, $42-71 \%$ carbohydrates, and $6-13 \%$ ash in the remaining part of $6-12 \%$ (Pekşen et al., 2016). Mushrooms are low-calorie foods because of their low dry matter and fat content. Nowadays, mushrooms are also important as a nutraceutical and dietary support (Üstün et al., 2018; Atri et al., 2019). Besides, they are widely used in medical, pharmaceutical, cosmetic, and commercial fields due to the secondary metabolites, carotenes, and antioxidants they contain (MartinezEspinosa et al., 2011; Bulam et al., 2018a). Due to their medical properties, they are used in traditional medicine in many countries (Boa, 2004; Lelley, 2005). Moreover, they contribute to the ecosystem and conservation of biodiversity as well as to the nutrient and carbon cycles (Martinez de Aragón et al., 2011; Buntgen et al., 2017).

It was reported in many studies that regarding the synthesis of toxic compounds caused by oxidative stress of mushrooms, they have enzymatic and non-enzymatic antioxidants (Barros et al., 2009; Robaszkiewicz et al., 2010; Georgescu et al., 2016; Bulam et al., 2018a; Bulam et al., 2018b; Turfan et al., 2018). Especially, parasol mushrooms are effective to prevent oxidative damage due to tocopherols, polyketides, steroids, terpenes, vitamins $C$ and $A$, flavones, and $\beta$-carotene they have (Rao and Rao, 2007; Robaszkiewicz et al., 2010). Turfan et al. (2019) investigated the anthocyanin, $\beta$-carotene, lycopene, phenolic, nitrate, soluble protein, proline, glucose, sucrose, and total carbohydrate levels and PAL activity of some mushrooms (Agaricus campestris, Cantharellus cibarius, Hericium erinaceus, and Lactarius piperatus).

Studies on the nutrient content and antioxidant properties of wild mushrooms grown in natural habitats and consumed as edible were very few until the last decade. However, studies on the functional use of edible mushrooms in Turkey and the world are showing an increasing trend. When studies on mushrooms in Turkey were viewed, studies on antioxidant enzymes of edible wild and cultivated mushrooms were found to be inadequate. In this study, it is aimed to determine nitrate, $\beta$-carotene, and lycopene content, phenylalanine ammonia lyase (PAL), ascorbate peroxidase (APX), peroxidase (POD), and superoxide dismutase (SOD) activities in 15 mushroom samples obtained from different locations in Turkey.

\section{MATERIAL AND METHOD}

\section{Supplying and Preparation of Mushroom Samples for the Analyses}

Information about mushroom samples is given in Table 1. The fruiting bodies (sporocarps) of wild edible species were collected from different provinces of Turkey during the spring and autumn seasons. Cultivated edible mushrooms were supplied from different mushroom production enterprises. Whole sporocarps consisted of pileus and stipes were used for analysis. All of the analyses were performed on the same mushroom sample lots with three replications. Fresh mushroom samples $(\sim 500 \mathrm{~g}$ for each replication of each mushroom species to use in analyses) were cut into small pieces and dried in an oven at $65^{\circ} \mathrm{C}$ to a constant weight. Then, the dried samples were ground into a fine powder using a laboratory mill. The ground samples were put into polyethylene bags, labeled, sealed, and kept at $4{ }^{\circ} \mathrm{C}$.

\section{Chemical Analysis}

The nitrate content of the mushrooms was determined using the rapid colorimetric method according to Cataldo et al. (1975). $500 \mathrm{mg}$ dry samples were homogenized in $10 \mathrm{ml}$ of de-ionized water at $45^{\circ} \mathrm{C}$ for an hour. After, the homogenate was centrifuged at $5000 \mathrm{rpm}$ for $20 \mathrm{~min}$. The supernatant was used for nitrate estimation. $200 \mu \mathrm{l}$ of the extract was mixed thoroughly with $800 \mu \mathrm{l}$ of $5 \%(\mathrm{w} / \mathrm{v})$ salicylic acid (prepared in concentrated $\mathrm{H}_{2} \mathrm{SO}_{4}$ ) in $50 \mathrm{ml}$ test tubes. Samples were kept at room temperature for 20 minutes and $10 \mathrm{ml}$ of $2 \mathrm{~N} \mathrm{NaOH}$ was put slowly. Then, all mixtures were cooled and absorbance was noted at $410 \mathrm{~nm}$. The amount of nitrate $\left(\mu \mathrm{g}\right.$ of $\mathrm{NO}_{3} \mathrm{~g}^{-1}$ dry weight) was estimated with a standard curve of $\mathrm{KNO}_{3}$.

Antioxidants were measured by using fresh leaf tissues $(500 \mathrm{mg})$, which were ground into powder using liquid nitrogen. These samples in $7 \mathrm{~mL}$ phosphate potassium $(\mathrm{pH} 7.6)$ with $0.1 \mathrm{mM}$ of EDTA and the homogenate were centrifuged to $10,000 \times \mathrm{g}$ for $15 \mathrm{~min}$ at $4^{\circ} \mathrm{C}$. The activity of SOD was determined by estimating its ability to inhibit the photochemical reduction of NBT (nitroblue tetrazolium), following Cakmak (1994). One unit of SOD was defined as the amount of enzyme necessary to cause $50 \%$ inhibition of the rate of NBT reduction at $560 \mathrm{~nm}$. 
Table 1. Information about mushroom species which were collected from different areas. Çizelge 1. Farklı yerlerden toplanan mantar türleri hakkında bilgi.

\begin{tabular}{|c|c|c|c|}
\hline Scientific name of mushroom & Common names & Wild/cultivated & Location \\
\hline Boletus edulis Bull.: Fr. & $\begin{array}{l}\text { Penny bun, Cep, Porcino, or } \\
\text { Porcini }\end{array}$ & Wild & Giresun \\
\hline Craterellus cornucopioides (L.) Pers. & $\begin{array}{l}\text { Horn of plenty, Black } \\
\text { chanterelle, Black trumpet }\end{array}$ & Wild & Samsun, Lâdik \\
\hline Ganoderma lucidum (Curt.: Fr.) P. Karst. & $\begin{array}{l}\text { Reishi or Lingzhi or Hemlock } \\
\text { varnish shelf }\end{array}$ & Cultivated & Denizli, Agroma \\
\hline Hericium erinaceus (Bull.: Fr.) Pers. & $\begin{array}{l}\text { Lion's mane mushroom, } \\
\text { Monkey head mushroom, } \\
\text { Bearded tooth mushroom, } \\
\text { Satyr's beard, Bearded } \\
\text { hedgehog mushroom, Pom } \\
\text { pom mushroom, or Bearded } \\
\text { tooth fungus }\end{array}$ & Cultivated & $\begin{array}{l}\text { Samsun Ondokuz } \\
\text { Mayıs Üniversitesi }\end{array}$ \\
\hline Lactarius deliciosus (L. ex Fr.) S.F.Gray & $\begin{array}{l}\text { Saffron milk cap or Red pine } \\
\text { Crab-of-the-woods }\end{array}$ & $\begin{array}{l}\text { Wild } \\
\text { Wild }\end{array}$ & Giresun, Bektaş \\
\hline Laetiporus sulphureus (Bull.: Fr.) Murr. & $\begin{array}{l}\text { Sulphur polypore, Sulphur } \\
\text { shelf, and Chicken-of-the- } \\
\text { woods }\end{array}$ & & Giresun, Bulancak \\
\hline Lentinula edodes (Berk.) Pegler & Shiitake mushroom & Cultivated & Denizli, Agroma \\
\hline Marasmius oreades (Bolt. ex Fr.) Fr. & $\begin{array}{l}\text { Fairy ring mushroom or Fairy } \\
\text { ring champignon }\end{array}$ & Wild & Sinop \\
\hline Morchella conica Pers. & $\begin{array}{l}\text { True morel, Black morel, or } \\
\text { Sponge mushroom }\end{array}$ & Wild & $\begin{array}{l}\text { Samsun, } \\
\text { Vezirköprü }\end{array}$ \\
\hline $\begin{array}{l}\text { Pleurotus ostreatus (Jacq. ex Fr.) P. Kumm.- } \\
1\end{array}$ & $\begin{array}{l}\text { Oyster, Abalone, or Tree } \\
\text { mushrooms }\end{array}$ & Cultivated & Giresun, Eynesil \\
\hline Pleurotus ostreatus (Jacq. ex Fr.) P. Kumm.-2 & & & Rize-Town \\
\hline Pleurotus ostreatus Jacq. ex Fr.) P. Kumm.-3 & & & Bursa \\
\hline Pleurotus ostreatus (Jacq. ex Fr.) P. Kumm.-4 & & & Rize-Centrum \\
\hline Ramaria botrytis (Pers.: Fr.) Ricken & $\begin{array}{l}\text { Clustered coral, Pink-tipped } \\
\text { coral mushroom, or Cauliflower } \\
\text { coral }\end{array}$ & Wild & Samsun, Lâdik \\
\hline Tricholoma terreum (Schaeff.: Fr.) P. Kumm. & Grey knight or Dirty Tricholoma & Wild & $\begin{array}{l}\text { Samsun, } \\
\text { Vezirköprü }\end{array}$ \\
\hline
\end{tabular}

APX was estimated by recording the decrease in absorbance at $290 \mathrm{~nm}$ because of the decrease in ascorbic acid content (Nakano and Asada, 1981). The activity of the POD was assayed according to Chance and Maehly (1955). The reaction mixture contained $50 \mu \mathrm{L}$ enzyme extract, $100 \mu \mathrm{L}$ of $40 \mathrm{mmol} \mathrm{L}^{-1} \mathrm{H}_{2} \mathrm{O}_{2}, 100 \mu \mathrm{L}$ of $30 \mathrm{mmol} \mathrm{L}^{-1}$ guaiacols, and $2.75 \mathrm{~mL}$ of $50 \mathrm{mmol} \mathrm{L}^{-1}$ sodium phosphate buffer ( $\left.\mathrm{pH} 7.0\right)$. The increase in absorbance was recorded at $470 \mathrm{~nm}$. APX and POD were expressed per $\mathrm{mg}$ protein and one unit represented $1 \mu \mathrm{mol}$ of a substrate undergoing reaction per $\mathrm{mg}$ protein per min.

PAL activity was determined by following the procedure given by Dickerson et al. (1984). $1 \mathrm{~g}$ sample was extracted with $3 \mathrm{ml}$ of $0.1 \mathrm{M}$ sodium borate buffer $(\mathrm{pH} 7.0)$ containing $1.4 \mathrm{mM}$ of 2-mercaptoethanol in an ice bath. The extract was filtered and centrifuged at $10.000 \times \mathrm{g}$ for $15 \mathrm{~min}$. Then, the supernatant was used for PAL activity. Enzyme activity was assayed as the rate of conversion of L-phenylalanine to trans-cinnamic acid at 290 $\mathrm{nm}$. Enzyme activity was expressed as nmol trans-cinnamic acid $\mathrm{min}^{-1} \mathrm{mg}^{-1}$ protein.

$\beta$-carotene and lycopene contents were measured according to Nagata and Yamashita (1992). Mushroom samples were extracted with acetone-hexane (4:6) at once, then, the optical density of the supernatant at $663 \mathrm{~nm}$, $645 \mathrm{~nm}, 505 \mathrm{~nm}$, and $453 \mathrm{~nm}$ were taken by spectrophotometer at the same time. The concentrations of $\beta$ carotene and lycopene in extracts were determined as spectrophotometric using the following equations:

$$
\begin{aligned}
& \beta \text {-carotene }=0.216 \times \mathrm{A}_{663}-1.22 \times \mathrm{A}_{645}-0.304 \times \mathrm{A}_{505}+0.452 \times \mathrm{A}_{453} \\
& \text { Lycopene }=-0.0458 \times \mathrm{A}_{663}+0.204 \times \mathrm{A}_{645}+0.372 \times \mathrm{A}_{505}-0.0806 \times \mathrm{A}_{453}
\end{aligned}
$$




\section{Statistical Analysis}

Analysis of variance (ANOVA) was applied for analyzing the differences in the chemical composition of edible mushroom species by using the SPSS program version 11.0 for Windows. Following the results of ANOVAs, Tukey's multiple test $(\alpha=0.05)$ was used for testing differences between group means.

\section{RESULTS AND DISCUSSION}

The $\beta$-carotene, lycopene, and nitrate contents, and APX, POD, SOD, and PAL activities values of 15 mushroom samples are given in Table 2 and 3, respectively. Results showed that the significant differences $(p<0.05)$ among the measured components for mushroom samples were found.

In respect of results acquired, the highest content of $\beta$-carotene was observed in $H$. erinaceus with $0.346 \mathrm{mg}$ $\mathrm{g}^{-1}$. This was followed by $P$. ostreatus -3 with $0.138 \mathrm{mg} \mathrm{g}^{-1}$. P. ostreatus $-2, P$. ostreatus -4, G. lucidum, and $P$. ostreatus -1 have been found to have less $\beta$-carotene content than the other mushroom species. Species rich in lycopene content were $H$. erinaceus, $P$. ostreatus-3, and G. lucidum, while $P$. ostreatus- $1, P$. ostreatus- 4 , and $T$. terreum had the least lycopene content (Table 2).

Table 2. $\beta$-carotene, lycopene and nitrate contents of mushroom species.

Çizelge 2. Mantar türlerinin $\beta$-karoten, likopen ve nitrat içerikleri.

\begin{tabular}{|c|c|c|c|}
\hline Name of mushroom species & $\begin{array}{c}\beta \text {-carotene } \\
\left(\mathrm{mg} \mathrm{g}^{-1}\right)\end{array}$ & $\begin{array}{l}\text { Lycopene } \\
\left(\mathrm{mg} \mathrm{g}^{-1}\right)\end{array}$ & $\begin{array}{l}\text { Nitrate } \\
\left(\mathrm{mg} \mathrm{g}^{-1}\right)\end{array}$ \\
\hline Boletus edulis & $0.044 \mathrm{e} \pm 0.001$ & $0.031 c \pm 0.001$ & $5.49 \mathrm{e} \pm 0.06$ \\
\hline Craterellus cornucopioides & $0.053 f \pm 0.001$ & $0.029 c \pm 0.001$ & $12.71 i \pm 0.11$ \\
\hline Ganoderma lucidum & $0.008 c \pm 0.40$ & $0.076 \mathrm{e} \pm 0.007$ & $6.04 f \pm 0.10$ \\
\hline Hericium erinaceus & $0.346 i \pm 0.012$ & $0.188 f \pm 0.003$ & $3.07 c \pm 0.01$ \\
\hline Lactarius deliciosus & $0.069 \mathrm{~g} \pm 0.001$ & $0.034 c \pm 0.002$ & $3.05 c \pm 0.03$ \\
\hline Laetiporus sulphureus & $0.071 \mathrm{~g} \pm 0.001$ & $0.034 c \pm 0.001$ & $3.15 c \pm 0.02$ \\
\hline Lentinula edodes & $0.054 f \pm 0.001$ & $0.032 c \pm 0.001$ & $6.50 \mathrm{~g} \pm 0.10$ \\
\hline Marasmius oreades & $0.089 h \pm 0.001$ & $0.059 d \pm 0.001$ & $9.16 ı \pm 0.06$ \\
\hline Morchella conica & $0.044 \mathrm{e} \pm 0.001$ & $0.018 b \pm 0.001$ & $3.74 d \pm 0.02$ \\
\hline Pleurotus ostreatus-1 & $0.009 c \pm 0.001$ & $0.008 a \pm 0.001$ & $1.77 b \pm 0.03$ \\
\hline Pleurotus ostreatus-2 & $0.002 a \pm 0.001$ & $0.030 c \pm 0.001$ & $6.50 \mathrm{~g} \pm 0.10$ \\
\hline Pleurotus ostreatus-3 & $0.138 ı \pm 0.001$ & $0.092 \mathrm{e} \pm 0.001$ & $0.40 \mathrm{a} \pm 0.00$ \\
\hline Pleurotus ostreatus-4 & $0.006 b \pm 0.001$ & $0.013 b \pm 0.001$ & $12.65 i \pm 0.10$ \\
\hline Ramaria botrytis & $0.056 f \pm 0.001$ & $0.039 d \pm 0.001$ & $8.48 h \pm 0.03$ \\
\hline Tricholoma terreum & $0.026 d \pm 0.001$ & $0.019 b \pm 0.001$ & $5.38 \mathrm{e} \pm 0.05$ \\
\hline Range (R) & 0.35 & 0.18 & 12.54 \\
\hline F value & 65.813 & 491.857 & 3369.590 \\
\hline Sig. level & 0.000 & 0.000 & 0.000 \\
\hline
\end{tabular}

Mushrooms are significant sources of food due to higher levels of protein, carotenoid, phenolic molecules, vitamins, minerals, enzymatic and non-enzymatic compounds, and lower values of calorie and fat. Because of having high antioxidant compounds, they can be considered as a functional food that provides health benefits (Ramkumar et al., 2010; Mueller and Boehm, 2011). $\beta$-carotene and lycopene are carotenoids, which are natural pigments present in different food sources such as vegetables, fruits, and mushrooms. They can neutralize free radicals by inhibiting the oxidation reactions with antioxidant properties and may stabilize them (Rao and Rao, 2007). They are synthesized via mevalonate pathway and may enhance taste, smell, and flavor of mushrooms (Barros et al., 2008b; Robaszkiewicz et al., 2010). In this study, the highest values of $\beta$-carotene and lycopene were recorded in $\mathrm{H}$. erinaceus, but the lowest $\beta$-carotene and lycopene values were observed in $P$. ostreatus- 2 and $P$. ostreatus-1, respectively (Table 2). Robaszkiewicz et al. (2010) in B. edulis, Cantharellus cibarius and Suillus bovinus, Barros et al. (2008a) in Agaricus bisporus and B. edulis, Jayakumar et al. (2009) in P. ostreatus, Zürcher et al. (1997) in $C$. cibarius determined higher $\beta$-carotene and lycopene according to the results of this study. Hussein et al. (2015) reported that Lentinus squarrolosus have higher $\beta$-carotene and lycopene than carrot, persimmon, and tomato.

Mushrooms are rich in nitrogenous compounds such as amino acid, protein, and enzymes. It has been shown that a high percentage of fat is taken along with protein compounds taken from animal foods (Martinez-Espinosa et al., 2011). Therefore, the mushrooms, which have very low fat in daily nutrition, can be benefit to consume only pure protein (Barros et al., 2008a). 
As seen in Table 2, the amount of nitrate ranged from 0.40 to $12.71 \mathrm{mg} \mathrm{g}^{-1}$. C. cornucopioides and $P$. ostreatus4 had the highest values with 12.71 and $12.65 \mathrm{mg} \mathrm{g}^{-1}$, respectively, while the lowest value was found in the $P$. ostreatus-3 with $0.40 \mathrm{mg} \mathrm{g}^{-1}$ (Table 2). There is a limited number of studies on the determination of nitrate level of mushrooms. However, Bobics et al. (2016) investigated nitrate content of saprophytic, mycorrhiza, and woody mushroom species, and the amount of nitrate was $216.5 \mathrm{mg} \mathrm{kg}^{-1}$ in the mycorrhiza species and $228.6 \mathrm{mg} \mathrm{kg}^{-1}$ in woody mushrooms. And also, in the saprophytic species, nitrate level varied between 151.40 and $12715 \mathrm{mg} \mathrm{kg}^{-1}$. Turfan et al. (2018) investigated the soluble protein level of the same mushroom species used in the study. Their results showed that the amounts of free amino acid ranged from 2.77 to $7.43 \mathrm{mg} \mathrm{g}^{-1}$, but total soluble protein contents varied 33.57 and $126.57 \mathrm{mg} \mathrm{g}^{-1}$. Ayaz et al. (2011) reported that the amount of nitrogen varied between

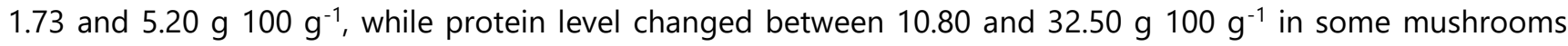
collected from Black Sea region. Also, Dembitsky et al. (2010) determined essential amino acid content of 15 wild edible mushrooms and they found that the amount of arginine as amino acid was the highest level compared to other amino acid varieties as $133 \mu^{\mathrm{M} \mathrm{g}^{-1}}$. Sun et al. (2017) determined that amino acid content changed between

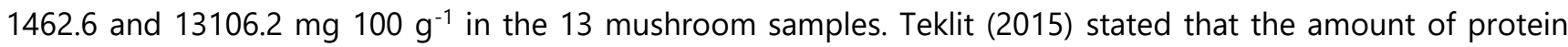

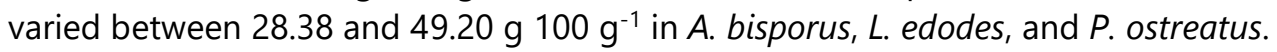

APX activity ranged from 0.201 and $2.118 \mathrm{EU} \mathrm{mg}^{-1}$ protein APX activities were quite low for $H$. erinaceus $(0.201$ EU mg ${ }^{-1}$ protein), C. cornucopioides (0.250 EU mg-1 protein), and G. lucidum (0.278 EU mg-1 protein). As shown in Table 3, P. ostreatus-4 had the highest APX value as $2.118 \mathrm{EU} \mathrm{mg}^{-1}$ protein among other mushroom samples. Also, it was found that APX activity values of $L$. edodes (1.711 $\mathrm{EU} \mathrm{mg}^{-1}$ protein), L. deliciosus (1.333 EU mg-1 protein), and T. terreum (1.057 EU $\mathrm{mg}^{-1}$ protein) were high.

Table 3. APX, POD, SOD, and PAL activity values of mushroom species. Çizelge 3. Mantar türlerinin $A P X, P O D$, SOD ve PAL aktivite değerleri.

\begin{tabular}{|c|c|c|c|c|}
\hline Name of mushroom species & $\begin{array}{c}\text { APX } \\
\text { (EU } \mathrm{mg}^{-1} \text { protein) }\end{array}$ & $\begin{array}{c}\text { POD } \\
\text { (EU } \mathrm{mg}^{-1} \text { protein) }\end{array}$ & $\begin{array}{c}\text { SOD } \\
\text { (EU } \mathrm{mg}^{-1} \text { protein) }\end{array}$ & $\begin{array}{c}\text { PAL } \\
\text { (EU } \mathrm{mg}^{-1} \text { protein) }\end{array}$ \\
\hline Boletus edulis & $0.397 c \pm 0.004$ & $0.206 a \pm 0.001$ & $23.87 b \pm 0.10$ & $8.893 e \pm 0.082$ \\
\hline Craterellus cornucopioides & $0.250 b \pm 0.002$ & $0.485 b \pm 0.001$ & $58.231 \pm 0.12$ & $6.362 a \pm 0.018$ \\
\hline Ganoderma lucidum & $0.278 b \pm 0.003$ & $2.472 ı 0.005$ & $33.34 \mathrm{~h} \pm 0.25$ & $5.863 a \pm 0.047$ \\
\hline Hericium erinaceus & $0.201 a \pm 0.002$ & $6.941 \mathrm{k} \pm 0.011$ & $35.13 ı \pm 0.15$ & $6.487 a \pm 0.031$ \\
\hline Lactarius deliciosus & $1.333 \mathrm{~h} \pm 0.009$ & $2.041 f \pm 0.003$ & $27.12 d \pm 0.13$ & $6.487 a \pm 0.031$ \\
\hline Laetiporus sulphureus & $0.735 e \pm 0.003$ & $1.645 e \pm 0.003$ & $31.42 g \pm 0.22$ & $5.899 a \pm 0.031$ \\
\hline Lentinula edodes & $1.711 ı 0.013$ & $0.844 d \pm 0.002$ & $48.48 \mathrm{k} \pm 0.06$ & $6.237 a \pm 0.018$ \\
\hline Marasmius oreades & $0.692 e \pm 0.006$ & $2.337 \mathrm{~h} \pm 0.070$ & $49.18 \mathrm{k} \pm 0.16$ & $8.145 d \pm 0.031$ \\
\hline Morchella conica & $0.772 f \pm 0.008$ & $2.179 g \pm 0.003$ & $30.13 f \pm 0.12$ & $6.861 b \pm 0.031$ \\
\hline Pleurotus ostreatus-1 & $0.623 d \pm 0.002$ & $0.435 b \pm 0.001$ & $21.81 b \pm 0.16$ & $6.754 b \pm 0.031$ \\
\hline Pleurotus ostreatus-2 & $0.603 d \pm 0.005$ & $0.285 a \pm 0.001$ & $24.36 c \pm 0.06$ & $6.273 a \pm 0.031$ \\
\hline Pleurotus ostreatus-3 & $0.780 f \pm 0.004$ & $4.760 \mathrm{j} \pm 0.002$ & $19.12 \mathrm{a} \pm 0.06$ & $7.289 c \pm 0.031$ \\
\hline Pleurotus ostreatus-4 & $2.118 i \pm 0.016$ & $0.722 c \pm 0.002$ & $46.49 \mathrm{j} \pm 0.12$ & $6.861 b \pm 0.031$ \\
\hline Ramaria botrytis & $0.700 \mathrm{~g} \pm 0.005$ & $0.429 b \pm 0.001$ & $28.28 e \pm 0.16$ & $8.216 d \pm 0.047$ \\
\hline Tricholoma terreum & $1.057 \mathrm{e} \pm 0.012$ & $3.160 i \pm 0.004$ & $39.35 i \pm 0.12$ & $6.647 b \pm 0.031$ \\
\hline Range (R) & 1.95 & 6.76 & 39.43 & 3.21 \\
\hline$F$ value & 5326.163 & 9696.766 & 6805.831 & 555.181 \\
\hline Sig. level & 0.000 & 0.000 & 0.000 & 0.000 \\
\hline
\end{tabular}

Beside of this, POD activity varied between 0.206 and $6.941 \mathrm{EU} \mathrm{mg}^{-1}$ protein. Also, the POD values of $H$. erinaceus, $P$. ostreatus-3, and $T$. terreum $\left(6.941,4.760\right.$ and $3.160 \mathrm{EU} \mathrm{mg}^{-1}$ protein, respectively) were higher than others. But, B. edulis (0.206 EU mg-1 protein) and P. ostreatus-2 (0.285 EU mg-1 protein) have come to the forefront as POD value low mushroom samples (Table 3 ). Considering the changes in enzymes activity, APX activities were the highest in the $P$. ostreatus $-4, L$. edodes, $L$. deliciosus and T. terreum. POD activities of the samples were the maximum in the $H$. erinaceus collected from the university campus, $P$. ostreatus-3, and $T$. terreum.

SOD activity of the samples ranged from 19.12 to $58.23 \mathrm{EU} \mathrm{mg}^{-1}$ protein. $C$. cornucopioides, $M$. oreades, and $L$. edodes were species which had the highest SOD activity whereas $P$. ostreatus $-3, P$. ostreatus $-1, B$. edulis, and $P$. ostreatus-2 were species that had the lowest SOD activity (Table 3). It has been shown by many searchers that mushrooms are abundant in antioxidant compounds as SOD, POD, CAT, and APX (Cai et al., 2006). Ramkumar et al. (2010) studied with nine mushroom species to determine CAT, SOD, and POD activities. They found that CAT, SOD and POD activities were 42.21, 37.12 and $7.21 \mu \mathrm{mol}$ respectively in the mushroom species. Georgescu et al. 
(2016) worked the effect of heavy metal stress on the activities of the enzymes of some mushroom species. Their result indicated that POD activity lowered with higher heavy metal accumulation, but CAT activity increased with higher concentration of heavy metals. Chen et al. (2017) investigated the effect of hydrogen-rish waters (HRW) on the Hypsizygus marmoreus depended on storage time. According to the result of them, SOD, CAT, APX, and GR activities enhanced with 25\% HRW. Besides, this concentration stimulated gene expression of some antioxidant enzymes in mushrooms.

It was determined that $B$. edulis was the richest species in terms of PAL activity among the studied mushrooms samples. Also, it was seen that the PAL activity of $B$. edulis was quite high, too. However, $C$. cornucopioides, $G$. lucidum, H. erinaceus, L. deliciosus, L. sulphureus, L. edodes, and P. ostreatus-2 were the poorest species in terms of PAL activity (Table 3). PAL is an important enzyme involved in the seconder metabolite metabolism in the plant cell. There are many workings on the importance of PAL in plants, but, the biological role of PAL in fungi and information on fungal PAL are not clear (Hyun et al., 2011). In this study, PAL activity also had significant effects among the mushroom samples. The highest level of PAL activity was observed with $B$. edulis. The lowest value of PAL was obtained from G. lucidum (Table 3). There is limited information on PAL activity in the literature on mushrooms. Hyun et al. (2011) reported that PAL activity was observed during organismal development and exposure to abiotic stress in P. ostreatus. Yun et al. (2015) investigated the cloning and activity of PAL in the mycelium and fruiting body of the edible mushroom Flammulina velutipes. The results showed that PAL activity varied in the different organs of the mushroom. Turfan et al. (2019) determined that PAL activities ranged between 5.79-6.99 EU mg-1 in different mushroom species.

When all chemical results were considered, the amount of chemical compound as antioxidants showed significant variations among mushroom samples collected from different areas. It has been shown that the amount of nutrient level and antioxidative chemicals may vary depending on species, in various parts of the fruiting body of mushrooms, seasonally as well changing of environmental conditions (Barros et al., 2009; Ayaz et al., 2016; Pekşen et al., 2016; Turfan et al., 2018).

\section{CONCLUSION}

Differences regarding the contents of chemical components of mushroom species were significant. These variations may result from location, ecological conditions, and also nutrient accumulation or antioxidant synthesis capacity as enzymatic and non-enzymatic. Also, examined 15 mushroom samples collected from different locations are a good source of $\beta$-carotene, lycopene, nitrate, and antioxidant enzyme activities such as APX, POD, SOD, and PAL. As a result, it can be said that these mushrooms are edible as alternative food supplements in daily nutrition.

\section{CONFLICT OF INTEREST}

The authors declare that there is no conflict of interests regarding the publication of this article.

\section{AUTHORS' CONTRIBUTIONS}

Nezahat TURFAN and Aysun PEKŞEN discussed the research concept and designed the experiment. Nezahat TURFAN, Sezgin AYAN ve Şeyma Selin AKIN carried out the experiment and statistical analysis which were finally verified. Aysun PEKŞEN wrote the manuscript with the support of other researchers.

\section{REFERENCES}

Atri, N. S., Sharma, Y. P., \& Kumar, S. M. (2019). Wild edible mushrooms of northwest Himalaya: Their nutritional, nutraceutical, and sociobiological aspects. In T. Satyanarayana, S. Kumar Das \& B. N. Johri (Eds.), Microbial Diversity in Ecosystem Sustainability and Biotechnological Applications. Springer, Singapore.

Ayaz, F. A., Torun, H., Özel, A., Col, M., Duran, C., Sesli, E., \&, Colak, A. (2011). Nutritional value of some wild edible mushrooms from the Black Sea region (Turkey). Turkish Journal of Biochemistry, 36(3), 213-221.

Ayaz, M., Junaid, M., Ullah, F., Sadiq, A., Ovais, M., Ahmad, W., \& Zeb, A. (2016). Chemical profiling, antimicrobial and insecticidal evaluations of Polygonum hydropiper L. BMC Complementary and Alternative Medicine, 16(1), 502. 
Barros, L., Venturini, B. A., Baptista, P., Estevinho, L. M., \& Ferreira, I. C. F. R. (2008a). Chemical composition and biological properties of Portuguese wild mushrooms: A comprehensive study. Journal of Agricultural and Food Chemistry, 56(10), 3856-3862.

Barros, L., Cruz, T., Baptista, P., Estevinho, L. M., \& Ferreira, I. C. F. R. (2008b). Wild and commercial mushrooms as source of nutrients and nutraceuticals. Food and Chemical Toxicology, 46, 2742-2747.

Barros, L., Duenas, M., Ferreira, I. C. F. R., Baptista, P., \& Santos-Buelga, C. (2009). Phenolic acids determination by HPLC-DADESI/MS in sixteen different Portuguese wild mushroom species. Food and Chemical Toxicology, 47, 1076-1079.

Boa, E. (2004). Wild Edible Fungi: A Global Overview of Their Use and Importance to People. Food and Agriculture Organization of the United Nations, Rome, Italy.

Bobics, R., Krüzselyi, D., \& Vetter, J. (2016). Nitrate content in a collection of higher mushrooms. Journal of the Science of Food and Agriculture, 30(2), 430-36.

Bulam, S., Üstün, N. Ş., \& Pekşen, A. (2018a). The most popular edible wild mushrooms in Vezirköprü district of Samsun province. Turkish Journal of Agriculture - Food Science and Technology, 6(2), 189-194.

Bulam, S., Üstün, N. Ş., \& Pekşen, A. (2018b). Edible wild mushroom antioxidants. International Eurasian Congress on Natural Nutrition \& Healthy Life (NATURAL 2018), Ankara, Turkey.

Buntgen, U., Latorre, J., Egli, S., \& Martínez-Peña, F. (2017). Socio-economic, scientific, and political benefits of mycotourism. Ecosphere, 8(7), 1870.

Cai, C., Xu, C.J., Li, X., Ferguson, I., \& Chen, K. S. (2006). Accumulation of lignin in relation to change in activities of lignification enzymes in loquat fruit flesh after harvest. Postharvest Biology and Technology, 40, 163-169.

Cakmak, I. (1994). Activity of ascorbate-dependent $\mathrm{H}_{2} \mathrm{O}_{2}$-scavenging enzymes and leaf chlorosis are enhanced in magnesium and potassium deficient leaves, but not in phosphorus deficient leaves. Journal of Experimental Botany, 45, 1259-1266.

Cataldo, D. A., Harcon, M., Schrader, L. E., \& Youngs, V. L. (1975). Rapid colorimetric determination of nitrate in plant tissue by nitration of salicylic acid. Communications in Soil Science and Plant Analysis, 6, 71-80.

Chance, B., \& Maehly, C. (1955). Assay of catalase and peroxidases. Methods in Enzymology, 2(11), 764-775.

Chen, H., Zhang, J., Hao, H., Feng, Z., Chen, M., Wang, H., \& Ye, M. (2017). Hydrogen-rich water increases postharvest quality by enhancing antioxidant capacity in Hypsizygus marmoreus. AMB Express, 7(1), 1-10.

Dembitsky, V. M., Terent'ev, A. O., \& Levitsky, D. O. (2010). Amino and fatty acids of wild edible mushrooms of the genus Boletus. Records of Natural Products, 4(4), 218-223.

Dickerson, D. P., Pascholati, S. F., Hagerman, A. E., Butler, L. G., \& Nicholson, R. L. (1984). Phenylalanine ammonia lyase and hydroxycinnamate: CoA ligase in maize mesocotyls inoculated with Helminthosporium maydis or Helminthosporium carbonum. Physiological Plant Pathology, 25, 111-123.

Georgescu, A. A., Danet A. F., Radulescu, C., Stihi, C., Dulama, I. D., \& Chelarescu, D. E. (2016). Determination of several elements in edible mushrooms using ICP-MS. Romanian Journal of Physics, 61(5-6), 1087-1097.

Hussein, J. M., Tibuhwa, D. D., Mshandete, A. M., \& Kivaisi, A. K. (2015). Antioxidant properties of seven wild edible mushrooms from Tanzania. African Journal of Food Science, 9(9), 471e9.

Hyun, M. W., Yun, Y. H., Kim, J. Y., \& Kim, S. H. (2011). Fungal and plant phenylalanine ammonia-lyase. Mycobiology, 39(4), 257265.

Jayakumar, T., Thomas, P.A. \& Geraldine, P. (2009). In vitro antioxidant activities of an ethanolic extract of the oyster mushroom, Pleurotus ostreatus. Innovative Food Science and Emerging Technologies, 10, 228-234.

Lelley, J. (2005). Modern applications and marketing of useful mushrooms. International Journal of Medicinal Mushrooms, 7(12), 39-48.

Martinez de Aragón, J., Riera, P., Giergiczny, M., \& Colinas, C. (2011). Value of wild mushroom picking as an environmental service. Forest Policy and Economics, 13(6), 419-424.

Martinez-Espinosa, R. M., Cole, J. A., Richardson, D. J., \& Watmough, N. J. (2011). Enzymology and ecology of the nitrogen cycle. Biochemical Society Transactions, 39, 175-178.

Mueller, L., \& Boehm, V. (2011). Antioxidant activity of $\beta$-carotene compounds in different in vitro assays. Molecules, 16, 10551069.

Nagata, M., \& Yamashita, L. (1992). Simple method for simultaneous determination of chlorophyll and carotenoids in tomato fruit. Nippon Shokuhin Kogyo Gakkaish, 39, 925-928. 
Nakano, Y., \& Asada, K. (1981). Hydrogen peroxide is scavenged by ascorbate-spesific peroxidase in spinach chloroplasts. Plant \& Cell Physiology, 22, 867-880.

Pekşen, A., Bulam, S., \& Üstün, N. Ş. (2016). Edible wild mushrooms sold in Giresun local markets. 1st International Mediterranean Science and Engineering Congress (IMSEC 2016), Çukurova University Congress Center, Adana, Turkey.

Ramkumar, L., Ramanathan, T., Thirunavukkarasu, P., \& Arivuselvan, N. (2010). Antioxidant and radical scavenging activity of nine edible mushroom extract. International Journal of Pharmacology, 6(6), 50-953.

Rao, A. V., \& Rao, L. G. (2007). Carotenoids and human health. Pharmacological Research, 55, 207-216.

Robaszkiewicz, A., Bartosz, G., Lawrynowicz, M., \& Soszynski, M. (2010). The role of polyphenols, $\beta$-carotene, and lycopene in the antioxidative action of the extract of dried edible mushrooms. Journal of Nutrition and Metabolism, 11, $173-274$.

Sun, L., Liu, Q., Bao, C., \& Fan, J. (2017). Comparison of free total amino acid compositions and their functional classifications in 13 wild edible mushrooms. Molecules, 22, 350.

Teklit, G. A. (2015). Chemical composition and nutritional value of the most widely used mushrooms cultivated in Mekelle Tigray Ethiopia. Journal of Nutrition \& Food Sciences, 5, 5.

Turfan, N., Ayan, S., Akın, Ş. S., \& Akın, E. (2019). Nutritional and antioxidant variability of some wild and cultivated edible mushrooms from Kastamonu rural areas. Turkish Journal of Agriculture-Food Science and Technology, 7(sp3), 11-16.

Turfan, N., Pekşen, A., Kibar, B., \& Ünal, S. (2018). Determination of nutritional and bioactive properties in some selected wild growing and cultivated mushrooms from Turkey. Acta Scientiarum Polonorum Hortorum Cultus, 17(3), 57-72.

Üstün, N. Ş., Bulam, S., \& Pekşen, A. (2018). The use of mushrooms and their extracts and compounds in functional foods and nutraceuticals. 1. International Technology Sciences and Design Symposium (ITESDES), Giresun University, Giresun, Turkey.

Wasser, S. P. (2014). Medicinal mushroom science: Current perspectives, advances, evidences, and challenges. Biomedical Journal, 37, 345-356.

Yun, Y. H., Koo, J. S., Kim, S. H., \& Kong, W. S. (2015). Cloning and expression analysis of phenylalanine ammonia-lyase gene in the mycelium and fruit body of the edible mushroom Flammulina velutipes. Mycobiology, 43(3), 327-332.

Zürcher, M., Niggli, U. A., Steck, A., \& Pfander, H. (1997). Oxidation of carotenoids- I. Dihydrooxepin derivatives as products of oxidation of canthaxanthin and $\beta$-carotene. Tetrahedron Letters, 38, 7853-7856. 